\section{The effect of cornorate governance and accruals quality on the corporate cash holdings: study on the manufacturing companies in Indonesian Stock Exchange}

Anggita Langgeng WIJAYA, PDIE Student of Universitas Sebelas Maret, Faculty of Economics and Business, Universitas PGRI Madiun, Kota Madiun, Indonesia, Email: Gonggeng14@gmail.com

BANDI,

Faculty of Economics and Business, Universitas Sebelas Maret, Kota Surakarta, Indonesia, Email: bandi.ssm@gmail.com

\section{Abstract}

This study objective was to examine the effect of corporate governance and the accruals quality on the corporate cash holdings. The research was conducted at manufacturing companies listed on the Indonesian Stock Exchange from 2009 to 2010. The study populations are all of manufacturing companies listed on the Indonesian Stock Exchange. The study samples are 143 companies taken using the purposive sampling method. The study hypothesis was tested using multiple linear regressions. The analysis results showed that: corporate governance positively affects corporate cash holdings; the accruals quality negatively affects corporate cash holdings.

Keywords: Corporate governance, accruals quality, cash holdings, manufacturing company.

JEL Classification: G34, M40

To cite this article:

Wijaya, A. L., Bandi (2018), The effect of corporate governance and accruals quality on the corporate cash holdings: study on the manufacturing companies in Indonesian Stock Exchange, Audit Financiar, vol. XVI, no. 3(151)/2018, pp. 415-424, DOI: 10.20869/AUDITF/2018/151/021

To link this article:

http://dx.doi.org/10.20869/AUDITF/2018/151/021

Received: 13.04.2018

Revised: 05.05.2018

Accepted: 16.07.2018 


\section{Introduction}

This study objective was to examine the effect of corporate governance and the accruals quality on the corporate cash holdings of the manufacturing companies listed at the Indonesian Stock Exchange for the period of 2009-2010. Ginglinger and Saddour (2007) stated that the determination of corporate cash holdings rate is one of the most important financial decisions of a finance manager. Ferreira and Vilela (2004) stated that by the end of 2000, most European Union companies had an average of $14.8 \%$ of cash and cash equivalents in the total composition of the company's assets. Duchin (2010) explained that companies in America had experienced a significant increase in cash ratio compared to total company assets. Data from 1990 to 2006 showed that companies in the US that have business diversification have cash holdings average of $11.9 \%$, while stand-alone companies hold more than $20.9 \%$ of the company's assets in cash (Duchin, 2010).

Couderc (2005) mentioned that corporate cash holdings are related to the company's efforts to minimize the external funding cost. The company has large sums of cash in the hope that the investment may be financed with internal funding sources, if the internal sources are lacking, then external funding is used. According to Couderc (2005), managers have an incentive to enlarge the company's free cash flow. This is because cash is the most manageable asset by managers. Managers have cash holdings in order to avoid financial distress in the future, invest when financial constraints increase and reduce costs incurred to acquire external funding and finance projects that suit the managers' interests.

According to Soddour (2006) in the perfect capital markets, holding large sums of cash is irrelevant. This is because companies will easily enter the market as well as they will easily obtain funds for their investment financing. However, in reality many studies have shown that many companies consider cash holdings to be an important thing that needs to be maintained at the optimum level to finance various corporate activities. Ditmar et al. (2003) explained that the implementation of corporate governance within the company is one of the factors that affect corporate cash holdings. This was related to agency issues and protection of shareholder rights. Ditmar et al. (2003) mentioned that if the shareholders rights protection is weak then the company will have a tendency to have large cash holdings in order to pay high agency fees. According to Couderc (2005), research on cash holdings was still considered not enough to prove the motivation of the company in holding cash in large amount, so it is necessary to do research about the factors that affect corporate cash holdings.

Teruel et al. (2009) stated that the accruals quality as a proxy of the financial statements quality is one of the factors that affect corporate cash holdings. Accruals quality negatively affects information asymmetry. If accruals quality is high then information asymmetry will be low. If the information asymmetry is low then the company will more easily obtain access to external funding, the certainty of the company's business risk is more predictable and thus, the company can have cash holdings in low amount. Dechow and Dichev (2002) explained that accruals quality was an accrual mapping of the realization of corporate cash flows where low levels of matching indicated low accruals quality. The low accruals quality raised both internal and external uncertainties that caused the company to hold cash in larger amount when compared to normal conditions. Mokhtari et al. (2012) mentioned that the financial report provided an overview of the company's ability to generate current cash flows and future cash flows. If the accruals quality presented in the financial statements is low then the users of the financial statements cannot measure the risk of the company's business in the future. This causes the company hold large amounts of cash in case of uncertainty in the future.

Chalaki et al. (2012) conducted a study on the effect of corporate governance to the corporate financial statements quality in Iran on the research period of 2003-2011. Chalaki et al. (2012) stated that the financial scandal that led to the bankruptcy of the company also led to act in the USA the Sarbanes-Oxley act which implicated to the high demands of corporate governance implementation. Klai and Omri (2011) explained that the implementation of corporate governance within a company was expected to improve the financial statements quality. The measurement model of the financial statements quality was disclosed in the research of Klai and Omri (2011) and Chalaki et al. (2012) used an accruals quality approach.

The research problem was motivated by the difference of research results and testing of corporate governance model, accruals quality and company cash holdings in previous researches. The research that examined the 
effect of corporate governance on company's cash holdings gave inconsistent results. The research conducted by Kusnaidi (2006), Ammann et al. (2011) found a negative influenced of corporate governance and company's cash holdings. Another study was conducted by Harford et al. (2008) and it stated that the effect of corporate governance on the corporate cash holdings is positive. Another research conducted by Ginglinger and Saddour (2007) showed that in companies without financial difficulties, there was no effect between corporate governance and company's cash holdings. Valipour et al. (2012) also found no significant effect of corporate governance and company's cash holdings. Previous researches that examined the effect of the accruals quality and company's cash holdings also gave inconsistent results. Teruel et al. (2009) found a negative effect of accruals quality on corporate cash holdings. Mokhtari et al. (2012) indicated that the accruals quality testing with discretionary accruals proxy did not significantly affect the corporate cash holdings while used nondiscretionary accruals proved to have significant effect on the cash holdings.

\section{Literature review and hynotheses development}

\subsection{Literature Review}

Mokhtari et al. (2012) stated that cash holdings are a very important component for each company's balance sheet. There are three theories that try to explain the decision of corporate cash holdings. First, Trade-off Theory (TOT) explained that the motive of having cash holdings is the consideration between the cost and the marginal profit from holding cash. The advantages of having cash holdings include preventing the occurrence of financial distress in the company, the accuracy of investment policy especially in case of financial difficulties, minimizing the cost of issuing new external funding sources, as well as preventing the liquidation of company assets. The cost of cash holdings is the opportunity cost that arises from the choice to invest in a liquid asset. The second theory is Pecking Order Theory (POT). This theory explained that to minimize the information asymmetry cost and other financing costs, the company must finance its investment with retained earnings first, issue secured debt, risky debt, and then equity. This theory explained that a company should not have a cash holdings target but need to maintain a balance between retained earnings and investment needs. The third theory is the theory of Free Cash Flow (FCF) revealed by Jensen (1986). This theory explained that managers have an incentive to form cash and increase the assets value in the management control in order to gain freedom in carrying out investments. Cash holdings reduced the pressure to the managers to make the best investments according to shareholder needs (Ferreira and Vilela, 2004).

Tsai (2012) stated that the main idea of corporate governance is ensuring accountability and assuring that individuals within the organization follow mechanisms that attempt to eliminate unfair practices within the company system. Tsai (2012) explained that corporate governance is closely related to the transparency aspects. The effectiveness of the corporate governance implementation in a company can be evaluated through the quality of the company's financial statements.

Ditmar et al. (2003) described one process that is closely related to the agency theory, that is the corporate governance. Klai and Omri (2011) were described the occurrence of major financial scandals in early 2000 as the Enron, Parmalat, and Worldcom cases which opened the eyes of many parties about the fragility of the protection system of shareholders' rights. Chalaki et al. (2012) stated the emergence of the Sarbanes-Oxley act which raised various rules on the protection of shareholder's interests. According to Chalaki et al. (2012), corporate governance is a set of regulatory processes that emerges so that shareholder rights as a company owner may remain well protected.

Valipour et al. (2012) conducted a research on the effect of corporate governance on the corporate cash holdings in Iranian companies. The research results indicated that the institutional ownership and the independent board, as a corporate governance mechanism in Iran, have no significant effect on corporate cash holdings policy. Denis and Silbilkov (2010) conducted research on financial difficulties, investments and the value of company cash holdings. The research result found that companies experiencing financial difficulties would hold cash in small amounts due to a small amount of cash flow. Duchin (2010) conducted a research on corporate cash holdings in relation to the diversification of the company's divisions. This study revealed that companies with diversified divisions have lower cash 
holdings than firms that do not have diversification divisions. Duchin (2010) also mentioned that there was a relationship between financial difficulties with respect to corporate governance and its relation to investment opportunities, when related to the company diversification and cash holdings.

Soltani and Ravanmehr (2011) conducted a research on corporate governance in relation to company cash holdings and corporate value. The research result indicated that independent commissioners as a component of corporate governance strongly affect the company value. Cash holdings have a negative effect on value. Companies that have too large cash holdings responded negatively on a market that considers large cash holdings as less productive assets. The research result also showed that a company with a low long-term debt has a higher corporate value. The research results of Toledo and Bocatto (2013) stated that investors' assessment in terms of corporate cash holdings was influenced by the corporate governance system in the company.

Klai and Omri (2012) stated that improvement of financial statements quality is one of the demands after the occurrence of various financial scandals in early 2000. Qualified financial statements were expected provide more appropriate accounting information and useful for business decisions of financial statements users. Verdi (2006) stated that the financial statements quality can be seen from the quality of the company's accruals. The company financial statements quality can improve the efficiency of company investment through efforts to reduce the asymmetry of information. Financial reports quality will reduce the information asymmetry between the firms and investors, reduce the adverse selection costs and lower corporate financing costs. In addition, the financial reports quality will reduce the information asymmetry between the investors and managers, reduce the agency conflict, lower the supervisory costs of managers and improve the project selection.

Doyle et al. (2007) stated that the company's accruals quality can be low for two reasons; first, management deliberately reports biased accruals due to earnings management measures; second, accidental mistakes in accrual judgments caused by difficulty in recording or difficulty in predicting future events or simply due to weak controls that cause errors in data reporting.
Dechow and Dichev (2002) stated that the accruals quality was not only limited to opportunistic corporate managers, but also to the was the difficulty to be determined, such as in cases of companies with special characters. Accruals quality was attributed to the company's cash flow. In general, the accruals quality will be low for companies with certain characters such as companies with high losses, fluctuating cash flows and sales, low total assets and longer company operational activities.

\subsection{Hypotheses Development}

Tsai (2012) stated that corporate governance is a mechanism related to the existence of agency problems in the company. Borhanuddin and Ching (2011) explained that the internal and external mechanisms of corporate governance were created with the intention of individuals in the company to keep working in line with the goals of the company owner. Harford et al. (2008) stated that corporate governance is one of the factors that affect corporate cash holdings policy. A study by Harford et al. (2008) in companies in the United States found a positive effect between the corporate governance and corporate cash holdings. The corporate governance in this study was measured by the corporate governance index. Firms with weak corporate governance structures have smaller cash reserves compared to firms with strong corporate governance structures. Harford et al. (2008) explained that the research results were in contradiction with the previous research based on a sample of inter-state enterprises, which found a negative relationship between the corporate governance and cash holdings.

Tsai (2012) conducted a research on corporate governance and cash holdings in companies affiliated to the Taiwan Stock Exchange in the period of 2005-2009. In theoretical explanation, this research explained that transparency and information disclosure are important aspects of corporate governance mechanism. Good corporate governance can limit the occurrence of high agency costs so that companies can hold cash in small amounts. Chen (2008) conducted a research on the effect of corporate governance on company's cash holdings by considering the investment opportunities and company types in the categories of new economic form and old economic form. The research results indicated that corporate governance mechanisms are able to reduce agency issues related to companies' cash 
holdings in the company type of old economic form. In new economic form company types, the influence of corporate governance on cash holdings is positive, as companies are more focused on the potential losses of investment cancellation, rather than the agency problem of cash flow.

Kusnaidi (2006) conducted a study on the corporate governance and cash holdings mechanisms of companies listed on the Malaysian and Singapore Stock Exchanges. This study used 445 sample companies in the period of 1999-2000. The study results indicated that internal corporate governance mechanisms in the form of director board characteristics and concentration ownership are important factors affecting cash holdings. The study results indicated that companies with weak corporate governance will make the company to hold cash in larger quantities compared to the strong corporate governance company. The effect of corporate governance on cash holdings is negative.

The research on the effect of corporate governance on cash holdings gave inconclusive results. Kusnaidi (2006) found a negative effect of corporate governance and cash holdings. Harford et al. (2008) found a positive influence of corporate governance and cash holdings. Valipour et al. (2012) stated that corporate governance was not a dominant factor that affects corporate cash holdings policy but corporate cash holdings are more dominantly affected by the company characteristics.

In this study, the researchers positioned the research hypothesis on the research results of Harford et al. (2008). The researchers suspected that in the sample companies in Indonesia, the effect of corporate governance and cash holdings is positive. This is because Indonesia's capital market was included in the category of emerging markets where there may be high levels of information asymmetry. According to Ozkan and Ozkan (2004) the high levels of information asymmetry will make expensive external financing costs so companies have to hold large amounts of cash. Ditmar et al. (2003) conducted an inter-state research related to the effect of corporate governance and cash holdings. Ditmar et al. (2003) categorized Indonesia as a country with a low level of shareholders' rights protection. According to Ditmar et al. (2003) in a country with weak shareholder protection, the company has a tendency to hold large amounts of cash due to the company's desire to obtain an easy funding source.
Based on the above statements, the hypothesis of this study was formulated as follows.

H1: Corporate governance positively affects corporate cash holdings.

Gray et al. (2008) mentioned that some studies had tried to link the financial statements quality and accruals quality to the information risk. The information risk is a risk that cannot be diversificated. The information risk raised the information asymmetry that caused some investors have more information compared to other investors. Profit provided a representation of potential future cash flows. The higher accruals quality, the better described will be the relationship between profit and cash flow that impacts on the low information risk so that the capital cost diminishes. Teruel et al. (2009) stated that good accruals quality decreased the level of information asymmetry so that the agency costs could be reduced, which affected the company cash holdings in small amounts.

Verdi (2006) discussed the agency theory in terms of information asymmetry by linking the financial statements quality and information asymmetry. This study argued that the financial statements quality could improve the efficiency of investment in the company through two ways: 1) the financial statements quality reducing the level of information asymmetry between firms and investors as well as lowering the cost of issuing new capital, 2) the financial statements quality reducing the level of information asymmetry between managers and thus, reducing the supervisory costs to managers and improving the project selection.

Accruals quality, according to Dechow and Dichev (2002), is related to the ability to calculate the company's cash flow. Accruals quality is useful for forecasting the future cash flows of the company used to determine the business risks of a company. Mokhtari et al. (2012) stated that poor accruals quality caused greater business risk to the investors due to high uncertainty aspects in the future. This situation occurs when the companies have poor accruals quality and the companies seek to have large cash holdings to overcome these uncertainties. Teruel et al. (2009) found that a company with poor accruals quality would have larger cash holdings when compared to a company with good accruals quality. The accruals quality contains information about the expected cash flow disclosed to 
the shareholders. The good accruals quality will impact on reporting earnings, which better represents the future cash flow, and thus, the amount of cash holdings in the balance sheet can be reduced. The companies with good accruals quality will reduce their cash amount in order to minimize the amount of current assets that are not productive in the company's balance sheet (Teruel et al., 2009).

Based on the above description, the study hypothesis was formulated as follows.

H2: Accruals quality negatively affects corporate cash holdings.

\section{Research methods}

The study populations are all of manufacturing companies listed on the Indonesia Stock Exchange. This study used secondary data from the financial statements of manufacturing companies in 2009-2010. The data analysis used the multiple linear regression. The first independent variable is the corporate governance. The corporate governance was measured using the corporate governance index referring to Sunhilde and Hajnalka (2009), Bekiris and Doukakis (2011), Bhuiyan et al. (2013), and Strydom et al. (2009). The corporate governance index comprises the following components: statements related corporate governance ( 3 items), information related ownership structure (4 items), investor relations (7 items), financial transparency (4 items), information related company commissioner (13 items), stakeholder role in corporate governance (6 items), remuneration (6 items), and audit (8 items). On the calculation of corporate governance index there are 50 items included into the statement. A score of 1 is given when the statement in the index is met and value 0 otherwise. The index measures good corporate governance practices in the company. The corporate governance index (ICG) is denoted by the following formula:

$$
\mathrm{ICG}=\frac{\text { Company } C G \text { index score }}{\text { CG index } \text { total }}
$$

The second independent variable is the accruals quality. Accruals quality was measured by accruals-cash flow approach, with reference to McNichols (2002). The accruals quality was calculated by the following formula.

$$
\begin{gathered}
W C A=\alpha+\beta 1 C F O_{t-1}+\beta 2 C_{C F O}+\beta 3 C^{2} O_{t+1}+\beta 4 \\
\triangle R E V+\beta 5 P P E+e
\end{gathered}
$$

Where:

$$
\begin{aligned}
& W C A=\text { Working Current Accrual } \\
& =\Delta \text { current assets }-\Delta \text { current debt }-\Delta \text { cash } \\
& \text { and cash equivalents, } \\
& \mathrm{CFO}_{\mathrm{t}-1}=\text { Operating cash flow year } \mathrm{t}-1 \\
& \mathrm{CFO}_{t}=\text { Operating cash flow year } \mathrm{t} \\
& \mathrm{CFO}_{t+1}=\text { Operating cash flow year } \mathrm{t}+1 \\
& \triangle R E V=\text { Revenue changes } \\
& P P E \quad=\text { Company fixed assets }
\end{aligned}
$$

The dependent variable is cash holdings. According to Teruel et al. (2009), cash holdings are the financial ratios that compare the amount of the company's cash with the amount of the company's assets out of cash. Cash holdings are denoted by the following formula.

$$
\text { Cash holdings }=\frac{\text { Cash }+ \text { cash equivalent }}{\text { TOtal asset }- \text { cash }}
$$

This research used leverage and company size as control variables. Leverage and company size were predicted to be factors that affect corporate cash holdings. The leverage was measured by total debt divided by total company assets while the company size was measured by the total natural log of company assets.

\subsection{Hypothesis Testing}

The regression equation was used as follows.

$$
\begin{aligned}
\mathrm{CASH}_{t+1}=\alpha & +\beta 1 I C G_{t}+\beta 2 A Q_{t}+\beta 3 L E V_{t} \\
& +\beta 4 L N S I Z E_{t}+e
\end{aligned}
$$

Where:

$$
\begin{array}{ll}
\mathrm{CASH}_{\mathrm{t}+1} & =\text { Cash holdings year } \mathrm{t}+1, \\
\mathrm{ICG}_{\mathrm{t}} & =\text { Index corporate governance year } \mathrm{t}, \\
A Q_{t} & =\text { Accruals quality year } t, \\
\mathrm{LEV}_{\mathrm{t}} & =\text { Leverage year } \mathrm{t}, \\
\mathrm{LNSIZE}_{\mathrm{t}} & =\text { Natural log of company size year } \mathrm{t}, \\
\beta 1-\beta 4 & =\text { Regression coefficient, } \\
\mathrm{e} & =\text { Error. }
\end{array}
$$




\section{Analysis and discussion}

\subsection{Data Collection Results}

The following table presents the results of the study sample selection.
From the table above there is known that the number of samples from 2009 to 2010 consists in 196 companies. The researcher tested outlier with the aim of obtaining data with normal distribution. Outlier test results showed there were 53 outlier data that must be excluded from the analysis. The number of samples consisted in 143 companies in the period of 2009-2010.

\begin{tabular}{|l|c|}
\hline \multicolumn{1}{|c|}{ Table no. 1. Sampling Results } & Amount \\
\hline Manufacturing companies listed on the Indonesia Stock Exchange & 137 \\
\hline A manufacturing company that publishes annual reports in 2009-2010 & 98 \\
\hline Number of observations during 2009-2010 & 196 \\
\hline Data not qualified (outlier) & 53 \\
\hline Number of samples & 143 \\
\hline
\end{tabular}

Source: The data collection results

\subsection{Descriptive Statistics}

The following table shows the results of the descriptive statistical test and correlation test of each research variable.

\section{Table 2. Descriptive Statistics}

\begin{tabular}{|l|c|c|c|c|c|}
\hline \multicolumn{1}{|c|}{ Variables } & N & Minimum & Maximum & Average & $\begin{array}{c}\text { Standard } \\
\text { Deviation }\end{array}$ \\
\hline ICG & 143 & 0.40 & 0.88 & 0.67 & 0.10 \\
\hline AQ & 143 & -0.07 & 1.46 & 0.66 & 0.21 \\
\hline LEV & 143 & 0.07 & 0.95 & 0.48 & 0.19 \\
\hline LNSIZE & 143 & 24.97 & 32.36 & 27.90 & 1.47 \\
\hline CASH & 143 & 0.00 & 0.61 & 0.10 & 0.12 \\
\hline
\end{tabular}

Source: Data processing results

The table above shows that the corporate governance index variables have a minimum value of 0.40 with a maximum value of 0.88 . The average value of corporate governance index is 0.67 with a standard deviation of 0.10 . The accruals quality variable has a minimum value of -0.07 with a maximum value of 1.46 . The average value of the company's accruals quality is 0.66 with a standard deviation of 0.21 . The leverage variable has a minimum value of 0.07 with a maximum value of 0.95 . The average leverage value is 0.48 with the standard deviation of 0.19 . The firm size variable has a minimum value of 24.97 with a maximum value of 32.36. The average value of firm size is 27.90 with standard deviation of 1.47 . The cash holding variable has a minimum value of 0.00 with a maximum value of 0.61 . The average value of cash holding is 0.10 with a standard deviation of 0.12 . The data used in this study passed the classical assumption test that includes test of data normality, test of autocorrelation, test of multicollinearity and test of heteroskedasticity.

\subsection{Hypothesis Testing}

The hypothesis testing used the multiple linear regressions. The test results from each hypothesis are as follows. 


\section{Table 3. Research Hypothesis Test}

\begin{tabular}{|l|c|c|}
\hline \multicolumn{3}{|c|}{ Equation: $\mathrm{CASH}_{\mathrm{t}+1}=\alpha+\beta 1 \mathrm{ICG}_{\mathrm{t}}+\beta 2 \mathrm{AQ}_{\mathrm{t}}+\beta 3 \mathrm{LEV}_{\mathrm{t}}+\beta 4 \mathrm{LNSIZE}_{\mathrm{t}}+\mathbf{e}$} \\
\hline \multicolumn{1}{|c|}{ Description } & Coefficient & The $\boldsymbol{p}$ value \\
\hline Constants & -0.108 & 0.530 \\
\hline ICG & 0.234 & 0.023 \\
\hline $\mathrm{AQ}$ & -0.102 & 0.019 \\
\hline LEV & -0.259 & 0.000 \\
\hline LNSIZE & 0.009 & 0.195 \\
\hline F-Value & 7,862 & 0.000 \\
\hline Adjusted R Square & 0.263 & \\
\hline
\end{tabular}

Source: Data processing results

From the table above there was known that the coefficient of determination showed the $R$ square value of 0.263 . This means that the $26.3 \%$ variation changes in the variable of company's cash holdings can be explained by corporate governance, the quality of the company's accruals, leverage and firm size. The remaining $73.3 \%$ is affected by other factors outside the research model. The result of $F$ test showed the $F$ value equal to 7,862 with $p$ value of 0.001 , so it can be concluded that the regression model fitted with the data used.

Hypothesis 1 objective examined the effect of corporate governance on company's cash holdings. The regression test results showed that the regression coefficient amounted to 0.234 with $p$ value of 0.023 . the regression test gives a significant result, so it can be concluded that corporate governance has a positive effect on corporate cash holdings. Hypothesis 1 is supported. The results of this study support the research results of Harford et al. (2008) who stated that the effect of corporate governance on cash holdings was positive. The study results also support the opinion that the Indonesian capital market is included in the category of emerging markets where there may be high levels of information asymmetry that impact on the expensive external financing costs. This causes the company to hold a large amount of cash as an easier source of funding. This result is in line with the research of Ditmar et al. (2003) who explained that the company holds large amounts of cash to finance various agency issues in the company.

Hypothesis 2 objective examined the effect of accruals quality on company's cash holdings. The regression test results showed a regression coefficient of -0.102 with $p$ value of 0.019 . the regression test gives a significant result, so it can be concluded that the accruals quality negatively affects corporate cash holdings. Hypothesis 2 is supported. The results of this study support the research results of Teruel et al. (2009). The study results indicated that the accruals quality negatively affects the company's cash holding. This indicated that the good accruals quality can lower the corporate cash holdings. The study results support the opinion of Teruel et al. (2009) who stated that the good accruals quality can decrease the level of information asymmetry and therefore, the agency costs can be suppressed, which had impact on companies in respect of holding cash in smaller amounts. The good accruals quality will impact on earnings reporting, which better represents the future cash flow, and thus, the amount of cash holdings in the balance sheet can be reduced. The study results also support the opinion of Verdi (2006) who stated that the financial statements quality could reduce the information asymmetry, and therefore, the cost of issuing new equity would be cheaper and the agency cost would be smaller.

Testing on leverage control variables provided significant results. Leverage negatively affects corporate cash holdings. The greater the leverage, the smaller the company's cash holdings will be. The study results indicated that the leverage was a substitute on the company's cash. The firms that are able to obtain easy funding accumulation will hold a larger amount of cash. Testing on control variables of company size gives insignificant results, therefore the company size does not affect the company's cash holdings. 


\section{Bonclusion}

This study objective was to examine the effect of corporate governance and the accruals quality on the corporate cash holdings in manufacturing companies listed on the Indonesia Stock Exchange from 2009 to 2010. Based on the analysis and discussion in the previous section, the researcher concludes that the corporate governance has a positive effect on the company cash holdings. The study results supported the results of the research performed by Harford et al. (2008) that found a positive effect of the corporate governance on the corporate cash holdings. The accruals quality negatively affects the corporate cash holdings. The study results support the study results of Teruel et al. (2009) which found a negative effect of the accruals quality on the corporate cash holdings.

This research has several weaknesses, such as the adoption of corporate governance index from Sunhilde and Hajnalka (2009), Bekiris and
Doukakis (2011). There are index points that contain multipoints in one index so it is quite difficult in the calculation of corporate governance index. This study period is relatively short because it only refers to the years 2009-2010. This research is only conducted on the type of manufacturing company so it cannot be used as a basis to generalize for all types of industries in the Indonesian Stock Exchange.

Further research is suggested to improve the corporate governance index measurement model used in this study. Further research is suggested to re-examine this research model used other proxies of corporate governance such as corporate governance mechanisms (managerial ownership, institutional ownership, board size, and independent commissioner). A subsequent research was suggested to consider the condition of companies that allegedly affect the companies' cash holdings such as financial distress and accounting conservatism.

\section{REFERENCES}

1. Ammann, M, David, O. and Markus M. S. (2011), Cash Holdings and Corporate Governance around the World, Working Paper University of St. Gallen.

2. Bekiris, F.F. and Doukakis, L.C, (2011), Corporate Governance and Accruals Earnings Management, Management and Decision Economic, vol. 32, pp. 439-356.

3. Bhuiyan, M. Borhan, U. Jamal, R. and Murray, C.. (2013), Corporate Governance Compliance and Discretionary Accruals: New Zealand Evidence, Australian Accounting Business \& Finance Journal, vol 7, issue 2, pp.87-109.

4. Borhanuddin, R.I. and Ching, P.W. (2011), Cash holdings, Leverage, Ownership Concentration and Board Independence: Evidence From Malaysia, Malaysian Accounting Review, vol. 10, no. 1, pp. 63-88.

5. Chalaki, P. Hamzeh, D. and Mohadeseh R. (2012), Corporate governance Attributes and Financial Reporting Quality: Empirical Evidence from Iran,
International Journal of Business and Social Science, vol. 3, no. 15, pp. 223-229.

6. Chen, Y.R. (2008), Corporate Governance and Cash holdings: Listed New Economy Versus Old Economy Firms, Journal Compilation Blackwell Publishing Ltd, vol. 16, no. 5, pp. 430-442.

7. Couderc, N. (2005), Corporate Cash Holdings: Financial Determinants and Consequences, Available on line at http:// www.univ-orleans.fr, accessed on March 21 th 2010.

8. Dechow, P. M. and Dichev, I.D. (2002), The Quality of Accruals and Earnings: The Role of Accrual Estimation Errors, The Accounting Review, vol. 77, issue 4 (October), pp. 35-59.

9. Denis, D.J. and Sibilkov, V. (2010), Financial Constraints, Investment, and The Value of Cash Holdings, The Review Of Financial Studies, vol. 23, no. 1, pp. 247-269.

10. Doyle, J.T. Weili, G. and Sarah M. (2007), Accruals Quality and Internal Control over Financial 
Reporting, The Accounting Review, vol.82, issue 5 (October), pp. 1141-1170.

11. Duchin, R. (2010), Cash Holdings and Corporate Diversification, The Journal Of Finance, vol. LXV, no. 3, pp. 955-992.

12. Ferreira, M.A. and Vilela, A.S. (2004), Why Do Firms Hold Cash? Evidence from EMU Countries, European Financial Management, vol. 10, no. 2, pp. 295-319.

13. Ginglinger, E. and Saddour, K. (2007), Cash Holdings, Corporate Governance and Financial Constraints, Available on line at http:// www.ssrn.com, accessed on March 21th 2010.

14. Gray, P. Ping-Sheng, K. and Yen H. T. (2008), Accruals Quality, Information Risk and Cost of Capital: Evidence from Australia, Journal of Business Finance \& Accounting, vol. 36, issue 1 (January), pp. 51-72.

15. Harford, J. Sattar. A. M. and William. F. M. (2008), Corporate Governance and Firm Cash Holdings in U.S, Journal of Financial Economics, vol. 87, pp. 535-555.

16. Jensen, M. C. (1986), Agency Costs of Free Cash Flow, Corporate Finance, and Takeovers, American Economic Review, vol. 76, issue 2 (May), pp. 323-329.

17. Jensen, M.C and. Meckling, W.H. (1976), Theory of The Firm: Managerial Behavior, Agency Cost and Ownership Structure, Journal of Financial Economics, vol. 3, issue 4 (October), pp. 305-360.

18. Klai, N. and Omri. A. (2011), Corporate Governance and Financial Reporting Quality: The Case of Tunisian Firms, International Business Research, vol. 4, no. 1, pp. 158-166.

19. McNichols, M.F. (2002), Discussion of the Quality of Accruals and Earnings: The Role of Accrual Estimation Errors, The Accounting Review, vol. 77, pp. 61-69.

20. Mokhtari, B. Saeid J.K. and Morteza M. (2012), The Investigation of the Relationship between Accruals Quality and Corporate Cash Holdings in Firms Listed in Tehran Stock Exchange (TSE), Journal of Management Research, vol. 4, no. 3, pp. 120-132.
21. Ozkan, A. and Ozkan.N. 2004. Corporate Cash Holdings: An Empirical Investigation of UK Companies. Journal of Banking and Finance. Vol. 28 Issue 9 (September), pp. 2103-2134.

22. Saddour, K. (2006), The Determinants and The Value of Cash Holdings: Evidence from French firms, Available on line at http:// www. dauphine.fr, accessed on December 1st, 2010.

23. Soltani, A. and Ravanmehr.N. (2011), Corporate Governance, Ownership Concentration, Cash Holdings and Firm Value on The Tehran Stock Exchange, Interdisciplinary Journal of Contemporary Research In Business, vol.3, no. 6, pp. 48-55.

24. Sunhilde, C. and Hajnalka, K. (2009), Corporate Governance- A Transparency Index for The Romanian Listed Companies, Economic Science Series, vol. 18, issue 2, pp. 60-66.

25. Strydom, M. Farshid N. Michael S. and Madhu V. (2009), The Effect of Corporate Governance Quality on the Accrual Anomaly. Available on line at http://www.buseco.monash.edu.au, Accessed on Mach 25th 2013.

26. Teruel, P.J.G. Pedro M.S. and Juan P.S.B. (2009), Accruals Quality and Corporate Cash Holdings, Journal compilation Accounting and Finance, vol. 49, issue 1 (March), pp. 95-115.

27. Toledo, E.P. and Bocatto. E. (2013), Quality of Governance and The Market Value of Cash: Evidence From Spain, The International Journal of Business and Finance Research, volume 7, number 2, pp. 91-104.

28. Tsai, Ching-Chieh. (2012), Cash Holdings and Corporate Governance in Business Group Affiliated Firms, International Conference on Economics Marketing and Management IPEDR, vol. 28, pp. 83-87.

29. Valipour, Hashem. Mohammad Monfared Maharlouie. and Mohammad Hadi Maher. (2012), Corporate Governance and Cash Holdings Policies:Evidence From Iran, American Journal of Scientific Research, issue 44 (2012), pp. 153-162.

30. Verdi, Rodrigo S. (2006), Financial Reporting Quality and Investment Efficiency, Available on line at http:// www.ssrn.com, accessed on June $17^{\text {th }}$, 2010. 